\title{
Ethnic inequalities in age- and cause-specific mortality in The Netherlands
}

\author{
Vivian Bos, ${ }^{1}$ Anton E Kunst, ${ }^{1}$ Ingeborg M Keij-Deerenberg, ${ }^{2}$ Joop Garssen ${ }^{2}$ and Johan P Mackenbach ${ }^{1}$
}

\begin{abstract}
Accepted 4 March 2004
Background By describing ethnic differences in age- and cause-specific mortality in The Netherlands we aim to identify factors that determine whether ethnic minority groups have higher or lower mortality than the native population of the host country.
\end{abstract}

Methods We used data for 1995-2000 from the municipal population registers and cause of death registry. All inhabitants of The Netherlands were included in the study. The mortality of people who themselves or whose parent(s) were born in Turkey, Morocco, Surinam, or the Dutch Antilles/Aruba was compared with that of the native Dutch population. Mortality differences were estimated by Poisson regression analyses and by directly standardized mortality rates.

Results Compared with native Dutch men, mortality was higher among Turkish (relative risk $[R R]=1.21,95 \%$ CI: 1.16, 1.26), Surinamese $(R R=1.24,95 \%$ CI: 1.19 , 1.29), and Antillean/Aruban ( $R R=1.25,95 \% C I: 1.15,1.36)$ males, and lower among Moroccan males $(\mathrm{RR}=0.85,95 \% \mathrm{CI}: 0.81,0.90)$. Among females, inequalities in mortality were small. In general, mortality differences were influenced by socio-economic and marital status. Most minority groups had a high mortality at young ages and low mortality at older ages, a high mortality from ill-defined conditions (which is related to mortality abroad) and external causes, and a low mortality from neoplasms. Cardiovascular disease mortality was low among Moroccan males ( $\mathrm{RR}=0.51,95 \% \mathrm{CI}: 0.44,0.59)$ and high among Surinamese males $(\mathrm{RR}=1.13,95 \% \mathrm{CI}: 1.05,1.21)$ and females $(\mathrm{RR}=$ 1.14, 95\% CI: 1.06, 1.23). Homicide mortality was elevated in all groups.

Conclusion Socio-economic factors and marital status were important determinants of ethnic inequalities in mortality in The Netherlands. Mortality from cardiovascular diseases, homicide, and mortality abroad were of particular importance for shifting the balance from high towards low all-cause mortality.

Keywords Ethnicity, mortality, inequality, cause of death, socio-economic status, marital status, The Netherlands

Results of studies examining the association between ethnicity and mortality in the UK and the US are varied, showing low mortality for some groups and high mortality for others. ${ }^{1-3}$ This occurs inspite of the fact that populations in non-Western

\footnotetext{
$\overline{1}$ Department of Public Health, Erasmus MC, University Medical Center Rotterdam, PO Box 1738, 3000 DR Rotterdam, The Netherlands.

2 Statistics Netherlands, PO Box 4000, 2270 JM Voorburg, The Netherlands. Correspondence: Vivian Bos MSc, Department of Public Health, Erasmus MC, University Medical Center Rotterdam, PO Box 1738, 3000 DR Rotterdam, The Netherlands. E-mail: v.bos@erasmusmc.nl
}

countries of origin almost universally have higher mortality rates than populations in countries of destination. ${ }^{4}$

To reduce excess mortality in ethnic minority or majority groups, one needs to understand the factors that determine these mortality differentials. In some studies, socio-economic inequalities have been reported to explain ethnic differences in mortality, but other studies suggest that they only have a minimal effect. ${ }^{5}$ The healthy migrant effect, the unhealthy re-migrant effect, racism, differences in genetic susceptibility, and differences in health-related behaviours are other candidate explanations of ethnic differences in mortality, but the extent to which these factors explain the inequalities is unclear. 
Looking at other national settings than the UK and the US can possibly help us to disentangle this myriad of explanations. In The Netherlands, about $10 \%$ of the population consists of people of non-Western origin. ${ }^{6}$ This group primarily consists of Turkish, Moroccans, Surinamese, and Antilleans/Arubans. Turkish and Moroccan men came as labour migrants to The Netherlands in the 1960s and 1970s and were later followed by their wives and children. The migration of the Surinamese population is mainly related to the political developments in Surinam and peaked in 1975 and 1980. The Surinamese population is ethnically diverse and consists of people who in turn originate from West Africa (30\%), India (37\%), Java $(15 \%)$, and China $(1,5 \%)$, and people of mixed origin. The Antillean and Aruban population consists predominantly of blacks descending from West Africa, whites and people of mixed origin, and its migration to The Netherlands has been relatively stable over time. These minority groups show some important similarities and differences with minority groups in other countries. The mortality patterns of these groups are, however, less well documented than other groups. Previous studies were carried out at the local level, used nationality as a proxy of ethnicity, and/or combined people originating from different countries into one category. ${ }^{7,8}$

This is the first study that provides an overview of age- and cause-specific inequalities in mortality by country of birth of subject and both parents for The Netherlands. It includes information on marital status, neighbourhood income, region, and degree of urbanization. We used these data to identify factors that determine whether minority groups have higher or lower mortality than the Dutch majority.

\section{Methods}

\section{Data}

We used data for the years 1995 through 2000 from the cause of death registry and the municipal population registers (GBA), which provided data on all inhabitants of The Netherlands with a legal status. These registers were linked on personal identification number. People were allowed to enter the study (through birth or immigration) throughout the study period (open cohort design). For each inhabitant, the amount of person time was calculated. We took into account the (multiple) date(s) of entry into the registry and the (multiple) date(s) of leaving the registry. The event of interest was death. Everyone included in the population registry that dies should be included in the cause of death registry, irrespective of whether the death occurred in the Netherlands or abroad. Thus, the mortality of those who die abroad is, to a certain but unknown extent, included in the cause of death registry, as long as they do not officially (r)emigrate. Those who unofficially emigrate but who are nonetheless lost in an administrative sense, are included in the Dutch population registry as 'administratively excluded'. By making assumptions about the mortality level of the latter we were able to estimate numbers of people who die abroad but who are not included in the cause of death registry (Discussionlimitations).

The causes of death are coded according to International Classification of Diseases, Ninth Revision (ICD-9) in 1995, and according to ICD-10 in 1996-2000 (Table 1). For deaths that
Table 1 International Classification of Diseases (ICD) codes for causes of death

\begin{tabular}{|c|c|c|}
\hline & $\begin{array}{l}\text { ICD-9 } \\
(1995) \\
\end{array}$ & $\begin{array}{r}\text { ICD-10 } \\
(1996-2000) \\
\end{array}$ \\
\hline Infectious diseases & $001-139$ & A00-B99 \\
\hline Neoplasms all & $140-239$ & C00-D48 \\
\hline Lung cancer & 162 & C33-C34 \\
\hline Stomach cancer & 151 & $\mathrm{C} 16$ \\
\hline Breast cancer & $174-175$ & $\mathrm{C} 50$ \\
\hline Cardiovascular diseases & $390-459$ & I00-I99 \\
\hline Ischaemic heart disease & $410-414$ & $\mathrm{I} 20-\mathrm{I} 25$ \\
\hline Other & $420-429$ & I30-I52 \\
\hline Cerebrovascular accidents & $430-438$ & I60-69 \\
\hline $\begin{array}{l}\text { Disease of respiratory } \\
\text { systems }\end{array}$ & $460-519$ & J00-J99 \\
\hline $\begin{array}{l}\text { Symptoms, signs, ill } \\
\text { defined }\end{array}$ & $780-799$ & R00-R99 \\
\hline Other diseases & All remaining & All remaining \\
\hline External causes & E800-E999 & V01-Y89 \\
\hline Suicide & E950-E959 & X60-X84 \\
\hline Homicide & E960-E969 & X85-Y09 \\
\hline
\end{tabular}

took place abroad, the cause is almost never established. These deaths are categorized under ill-defined conditions. Among Turkish and Moroccans, $80 \%$ of deaths within this category took place abroad, among Surinamese and Antilleans/Arubans $50 \%$, and among Dutch $13 \%$.

We used country of birth of subject and both parents to approximate ethnicity. We applied the standard definition of foreigners of Statistics Netherlands and considered a person to be Non-Dutch if at least one parent was born abroad. ${ }^{9}$ Therefore, this study includes people who migrated to The Netherlands themselves and those who were born in The Netherlands with at least one parent born abroad.

Five-year age categories were used. All data were tabulated according to sex, date of birth, country of birth, country of birth of both parents, six-digit post code, and marital status (unmarried, married, widowed, or divorced). With six-digit post code, we linked our data to a file that contained information on region (West, East, South, and North), degree of urbanization (address-density per square kilometre classified into five categories) and socio-economic status (mean household equivalent income of neighbourhoods classified into deciles that each contained $10 \%$ of person years). Although our indicator of socio-economic status is an ecological measure, it was able to demonstrate socio-economic differences in mortality and it proved to be relatively robust for confounding. ${ }^{10,11}$

\section{Statistical analysis}

We estimated the size of relative mortality differences between the minority groups and the native Dutch population by means of Poisson regression analyses (using Stata version 7). We related the number of deceased to the amount of observed person time as offset variable, and to country of origin as 
Table 2 Background characteristics for each ethnic group by sex

\begin{tabular}{|c|c|c|c|c|c|}
\hline & Dutch & Turkish & Moroccans & Surinamese & $\begin{array}{c}\text { Antilleans/ } \\
\text { Arubans }\end{array}$ \\
\hline \multicolumn{6}{|l|}{ Male } \\
\hline \multicolumn{6}{|l|}{ Person years $(* 1000)$} \\
\hline $0-19$ & 9350 & 373 & 343 & 295 & 108 \\
\hline $20-39$ & 11985 & 366 & 282 & 310 & 109 \\
\hline $40-64$ & 12582 & 156 & 146 & 191 & 45 \\
\hline $65+$ & 4677 & 9 & 9 & 21 & 3 \\
\hline Total & 38594 & 905 & 781 & 816 & 265 \\
\hline \multicolumn{6}{|l|}{ No. of deaths } \\
\hline $0-19$ & 5139 & 303 & 270 & 165 & 66 \\
\hline $20-39$ & 9381 & 362 & 256 & 414 & 145 \\
\hline $40-64$ & 69140 & 1023 & 601 & 1269 & 246 \\
\hline $65+$ & 285222 & 346 & 198 & 1047 & 119 \\
\hline Total & 368882 & 2034 & 1325 & 2895 & 576 \\
\hline Marital status: \% unmarried (aged 30-49 years) & 25.5 & 6.7 & 13.2 & 36.5 & 53.1 \\
\hline Region: \% living in West & 30.5 & 35.4 & 39.9 & 42.5 & 38.7 \\
\hline Degree of urbanization: \% living in highly urbanized area & 17.6 & 21.1 & 21.4 & 22.9 & 21.4 \\
\hline Socio-economic status: \% living in low income area & 16.4 & 58.7 & 56.1 & 50.8 & 43.7 \\
\hline \multicolumn{6}{|l|}{ Female } \\
\hline \multicolumn{6}{|l|}{ Person years $\left({ }^{*} 1000\right)$} \\
\hline $0-19$ & 8944 & 352 & 330 & 285 & 104 \\
\hline $20-39$ & 11544 & 324 & 235 & 348 & 106 \\
\hline $40-64$ & 12350 & 126 & 98 & 208 & 51 \\
\hline $65+$ & 6754 & 10 & 4 & 37 & 7 \\
\hline Total & 39592 & 812 & 667 & 879 & 268 \\
\hline \multicolumn{6}{|l|}{ No. of deaths } \\
\hline $0-19$ & 3525 & 223 & 196 & 108 & 39 \\
\hline $20-39$ & 5599 & 152 & 107 & 227 & 77 \\
\hline $40-64$ & 42969 & 343 & 231 & 694 & 161 \\
\hline $65+$ & 317889 & 233 & 87 & 1366 & 210 \\
\hline Total & 369982 & 951 & 621 & 2395 & 487 \\
\hline Marital status: \% unmarried (aged 30-49 years) & 16.8 & 3.3 & 3.9 & 30.8 & 44.5 \\
\hline Region:\% living in West & 30.3 & 36.4 & 40.8 & 44.0 & 40.5 \\
\hline Degree of urbanization: \% living in highly urbanized area & 17.3 & 21.1 & 20.6 & 22.5 & 21.0 \\
\hline Socio-economic status: \% living in low income area & 16.6 & 583 & 55.6 & 49.4 & 43.0 \\
\hline
\end{tabular}

independent variable. All relative risks (RR) were adjusted for differences in age structure. Regression analyses were done with and without adjustment for differences in marital status, region, degree of urbanization, and socio-economic status. These variables were included in the regression analyses as categorical variables.

The mortality level of each ethnic group was measured by means of directly age-standardized mortality rates. Since the ethnic minority population in The Netherlands is still quite young, we used the sum of the studied minority populations in
The Netherlands as standard population. Absolute differences in mortality rates between minority groups and native Dutch were calculated for total and cause-specific mortality. Life expectancies were calculated by means of abridged life table analyses.

\section{Results}

Minority groups were younger than the Dutch population (Table 2). Turkish and Moroccans were often married, while 
Table 3 Mortality rate ratios for ethnic minorities versus native Dutch by sex after adjustment for age and, alternatively, for marital status, region, degree of urbanization, and socio-economic status

\begin{tabular}{|c|c|c|c|c|}
\hline & \multicolumn{4}{|l|}{ RR $(95 \%$ CI) } \\
\hline & Turkish & Moroccans & Surinamese & Antilleans/Arubans \\
\hline \multicolumn{5}{|c|}{ Adjusted for age } \\
\hline Male & $1.21(1.16,1.26)$ & $0.85(0.81,0.90)$ & $1.24(1.19,1.29)$ & $1.25(1.15,1.36)$ \\
\hline Female & $1.00(0.94,1.07)$ & $0.98(0.90,1.06)$ & $1.10(1.06,1.15)$ & $1.08(0.99,1.18)$ \\
\hline \multicolumn{5}{|c|}{ Adjusted for age and marital status } \\
\hline Male & $1.28(1.22,1.34)$ & $0.89(0.85,0.94)$ & $1.13(1.09,1.17)$ & $1.13(1.04,1.23)$ \\
\hline Female & $1.02(0.96,1.09)$ & $1.00(0.92,1.08)$ & $1.02(0.98,1.06)$ & $1.00(0.91,1.09)$ \\
\hline \multicolumn{5}{|c|}{ Adjusted for age and region } \\
\hline Male & $1.21(1.16,1.27)$ & $0.86(0.81,0.91)$ & $1.26(1.21,1.31)$ & $1.26(1.16,1.37)$ \\
\hline Female & $1.00(0.94,1.07)$ & $0.98(0.91,1.06)$ & $1.11(1.07,1.16)$ & $1.08(0.99,1.18)$ \\
\hline \multicolumn{5}{|c|}{ Adjusted for age and degree of urbanization } \\
\hline Male & $1.16(1.11,1.22)$ & $0.82(0.77,0.86)$ & $1.19(1.14,1.23)$ & $1.21(1.11,1.31)$ \\
\hline Female & $0.99(0.92,1.05)$ & $0.96(0.89,1.04)$ & $1.08(1.04,1.13)$ & $1.06(0.97,1.16)$ \\
\hline \multicolumn{5}{|c|}{ Adjusted for age and socio-economic status } \\
\hline Male & $1.08(1.03,1.13)$ & $0.77(0.73,0.82)$ & $1.15(1.11,1.20)$ & $1.15(1.05,1.26)$ \\
\hline Female & $0.95(0.88,1.02)$ & $0.94(0.86,1.02)$ & $1.06(1.01,1.10)$ & $1.03(0.93,1.13)$ \\
\hline \multicolumn{5}{|c|}{ Adjusted for age, marital status, region, degree of urbanization, and socio-economic status } \\
\hline Male & $1.16(1.10,1.21)$ & $0.82(0.77, .87)$ & $1.07(1.03,1.11)$ & $1.06(0.96,1.15)$ \\
\hline Female & $0.98(0.91,1.05)$ & $0.97(0.89,1.06)$ & $0.99(0.95,1.03)$ & $0.96(0.87,1.06)$ \\
\hline
\end{tabular}

Surinamese and Antilleans/Arubans were frequently single. All minority groups lived more frequently in neighbourhoods with a low socio-economic status.

After controlling for differences in age structure, Turkish, Surinamese, and Antillean/Aruban males had an approximately $25 \%$ higher risk of dying than native Dutch males, while Moroccan males had an approximately 15\% lower risk of dying (Table 3). For females, only among Surinamese the mortality rate ratios were significantly different (higher) than that of Dutch. Results from life table analyses confirmed the observed mortality differences (results not presented). The mortality level of most groups was influenced by socioeconomic status, while adjustment for region and degree of urbanization did not make a meaningful difference. The mortality level of Surinamese males and females and Antillean males were related to marital status.

Age-specific rate ratios varied with age (Figures la and $1 b$ ). Generally, members of the minority groups had an excess mortality at young ages and a reduced mortality at older ages. The age at which the high mortality turned into a low mortality varied somewhat, but was located around about age 35 . Turkish and Surinamese men above age 35 did not have a mortality advantage. Adjustment for socio-economic inequalities reduced mortality differences to a larger extent at younger ages than at older ages (results not shown).

After adjustment for a number of variables, ethnic differences in mortality were significant for many causes of death (Table 4). Most minority groups had an excess mortality from infectious diseases and a reduced mortality from neoplasms. Lung cancer mortality was low for all groups and breast cancer mortality was
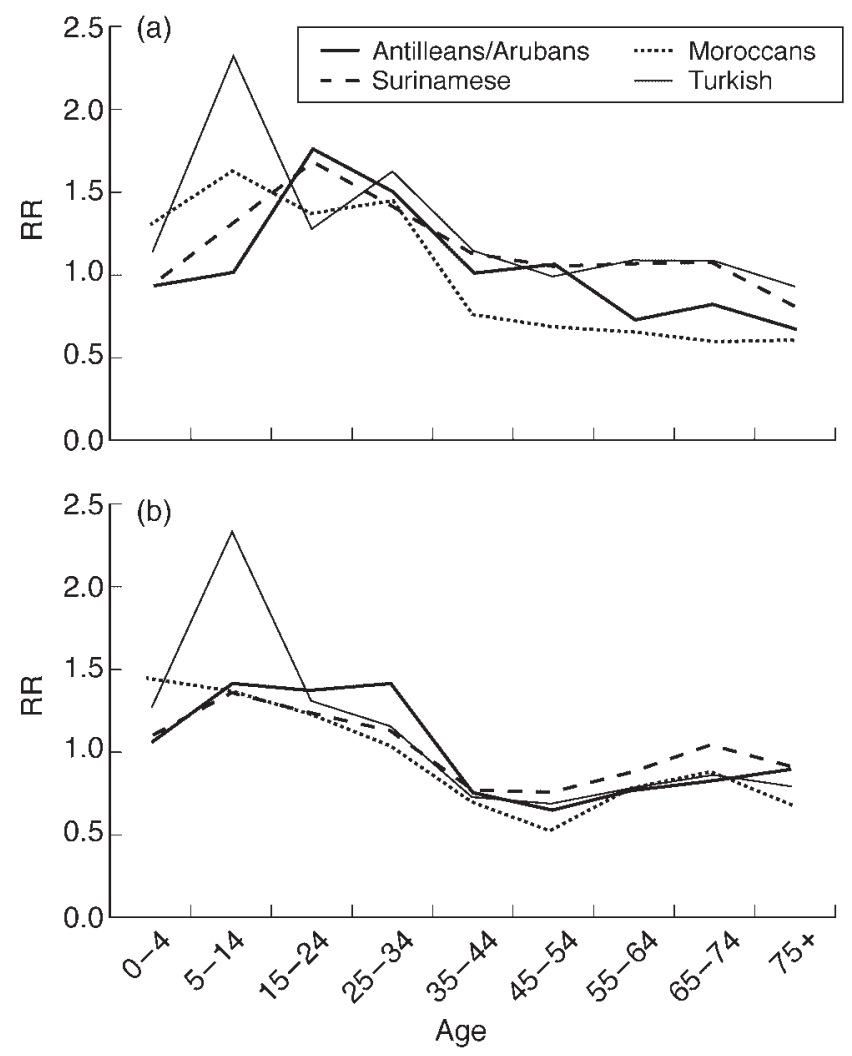

Figure 1 Mortality rate ratios for ethnic minority groups versus the native Dutch population by ages: (a) Males, (b) Females 
Table 4 Mortality rate ratios for specific causes of death for ethnic minorities versus native Dutch after adjustment for age, marital status, region, degree of urbanization, and socio-economic status by sex

\begin{tabular}{|c|c|c|c|c|}
\hline & \multicolumn{4}{|l|}{ RR $(95 \%$ CI $)$} \\
\hline & Turkish & Moroccans & Surinamese & Antilleans/Arubans \\
\hline \multicolumn{5}{|l|}{ Male } \\
\hline Infectious diseases & $1.25(0.88,1.79)$ & $1.07(0.72,1.59)$ & $2.21(1.79,2.73)$ & $2.87(1.98,4.16)$ \\
\hline Neoplasms all & $0.63(0.57,0.71)$ & $0.47(0.41,0.54)$ & $0.62(0.56,0.68)$ & $0.83(0.69,1.01)$ \\
\hline Lung cancer & $0.68(0.56,0.83)$ & $0.45(0.36,0.58)$ & $0.38(0.31,0.47)$ & $0.68(0.46,1.01)$ \\
\hline Stomach cancer & $1.11(0.74,1.66)$ & $0.90(0.57,1.42)$ & $1.30(0.95,1.77)$ & $1.80(0.97,3.35)$ \\
\hline $\begin{array}{l}\text { Cardiovascular } \\
\text { diseases all }\end{array}$ & $0.98(0.88,1.08)$ & $0.51(0.44,0.59)$ & $1.13(1.05,1.21)$ & $0.83(0.69,1.02)$ \\
\hline $\begin{array}{l}\text { Ischaemic heart } \\
\text { disease }\end{array}$ & $0.92(0.79,1.06)$ & $0.40(0.32,0.51)$ & $0.93(0.83,1.03)$ & $0.66(0.48,0.91)$ \\
\hline Other & $0.75(0.61,0.91)$ & $0.42(0.32,0.56)$ & $0.91(0.80,1.04)$ & $0.50(0.33,0.76)$ \\
\hline Cerebrovascular accidents & $1.44(1.14,1.82)$ & $1.01(0.76,1.35)$ & $1.90(1.66,2.17)$ & $1.20(0.79,1.82)$ \\
\hline $\begin{array}{l}\text { Diseases of } \\
\text { respiratory system }\end{array}$ & $0.73(0.55,0.98)$ & $0.71(0.52,0.97)$ & $0.67(0.56,0.81)$ & $0.92(0.61,1.38)$ \\
\hline $\begin{array}{l}\text { Symptoms, signs, ill } \\
\text { defined conditions }\end{array}$ & $6.30(5.71,6.96)$ & $3.23(2.83,3.70)$ & $1.98(1.74,2.24)$ & $1.41(1.03,1.93)$ \\
\hline Other diseases & $0.91(0.80,1.04)$ & $0.97(0.85,1.11)$ & $1.15(1.05,1.27)$ & $0.87(0.69,1.10)$ \\
\hline External causes all & $1.24(1.07,1.42)$ & $1.15(0.99,1.33)$ & $1.33(1.19,1.48)$ & $1.43(1.18,1.74)$ \\
\hline Suicide & $0.85(0.65,1.12)$ & $0.64(0.46,0.88)$ & $1.13(0.94,1.36)$ & $1.04(0.73,1.48)$ \\
\hline Homicide & $4.29(3.08,5.98)$ & $3.30(2.28,4.77)$ & $2.66(1.94,3.65)$ & $7.07(4.99,10.03)$ \\
\hline \multicolumn{5}{|l|}{ Female } \\
\hline Infectious diseases & $1.92(1.27,2.90)$ & $2.42(1.58,3.69)$ & $1.80(1.35,2.40)$ & $2.58(1.55,4.30)$ \\
\hline Neoplasms all & $0.47(0.40,0.56)$ & $0.39(0.31,0.48)$ & $0.58(0.53,0.64)$ & $0.66(0.54,0.80)$ \\
\hline Lung cancer & $0.19(0.11,0.33)$ & $0.07(0.02,0.21)$ & $0.24(0.17,0.33)$ & $0.30(0.15,0.59)$ \\
\hline Breast cancer & $0.43(0.31,0.61)$ & $0.41(0.27,0.63)$ & $0.52(0.42,0.65)$ & $0.81(0.56,1.17)$ \\
\hline Stomach cancer & $1.78(1.05,3.02)$ & $0.59(0.19,1.85)$ & $1.30(0.88,1.90)$ & $1.73(0.82,3.63)$ \\
\hline $\begin{array}{l}\text { Cardiovascular } \\
\text { diseases all }\end{array}$ & $0.87(0.74,1.02)$ & $0.85(0.68,1.06)$ & $1.14(1.06,1.23)$ & $0.99(0.82,1.20)$ \\
\hline $\begin{array}{l}\text { Ischaemic heart } \\
\text { disease }\end{array}$ & $0.63(0.46,0.87)$ & $0.73(0.49,1.08)$ & $1.01(0.89,1.16)$ & $0.87(0.62,1.23)$ \\
\hline Other & $0.78(0.59,1.03)$ & $0.89(0.63,1.27)$ & $0.96(0.84,1.09)$ & $0.49(0.32,0.76)$ \\
\hline $\begin{array}{l}\text { Cerebrovascular } \\
\text { accidents }\end{array}$ & $0.94(0.69,1.28)$ & $0.75(0.47,1.19)$ & $1.37(1.20,1.56)$ & $1.11(0.79,1.56)$ \\
\hline $\begin{array}{l}\text { Diseases of } \\
\text { respiratory system }\end{array}$ & $0.54(0.35,0.82)$ & $0.65(0.38,1.10)$ & $0.78(0.65,0.93)$ & $0.56(0.34,0.92)$ \\
\hline $\begin{array}{l}\text { Symptoms, signs, ill } \\
\text { defined conditions }\end{array}$ & $5.73(4.94,6.64)$ & $4.84(3.99,5.88)$ & $1.61(1.37,1.88)$ & $2.02(1.47,2.76)$ \\
\hline Other diseases & $0.95(0.81,1.11)$ & $1.13(0.96,1.33)$ & $1.15(1.05,1.26)$ & $0.87(0.68,1.10)$ \\
\hline External causes all & $0.91(0.70,1.17)$ & $0.98(0.74,1.30)$ & $0.99(0.83,1.18)$ & $1.00(0.71,1.41)$ \\
\hline Suicide & $0.54(0.32,0.93)$ & $0.49(0.26,0.92)$ & $0.77(0.59,1.02)$ & $0.64(0.35,1.16)$ \\
\hline Homicide & $2.09(1.12,3.93)$ & $3.30(1.86,5.87)$ & $2.70(1.71,4.25)$ & $2.04(0.83,5.02)$ \\
\hline
\end{tabular}

low among women. Mortality from ischaemic heart disease was low for Moroccan and Antillean/Aruban males and for Turkish females. Mortality from stroke was elevated for Surinamese males and females and for Turkish males. Most groups had a low probability of dying from respiratory diseases. Mortality from ill-defined conditions was high in all groups. Turkish, Surinamese, and Antillean males had an elevated mortality from external causes. All minority groups, and Antillean/Aruban males in particular, had a strongly elevated mortality from homicide. In comparison with other causes of 

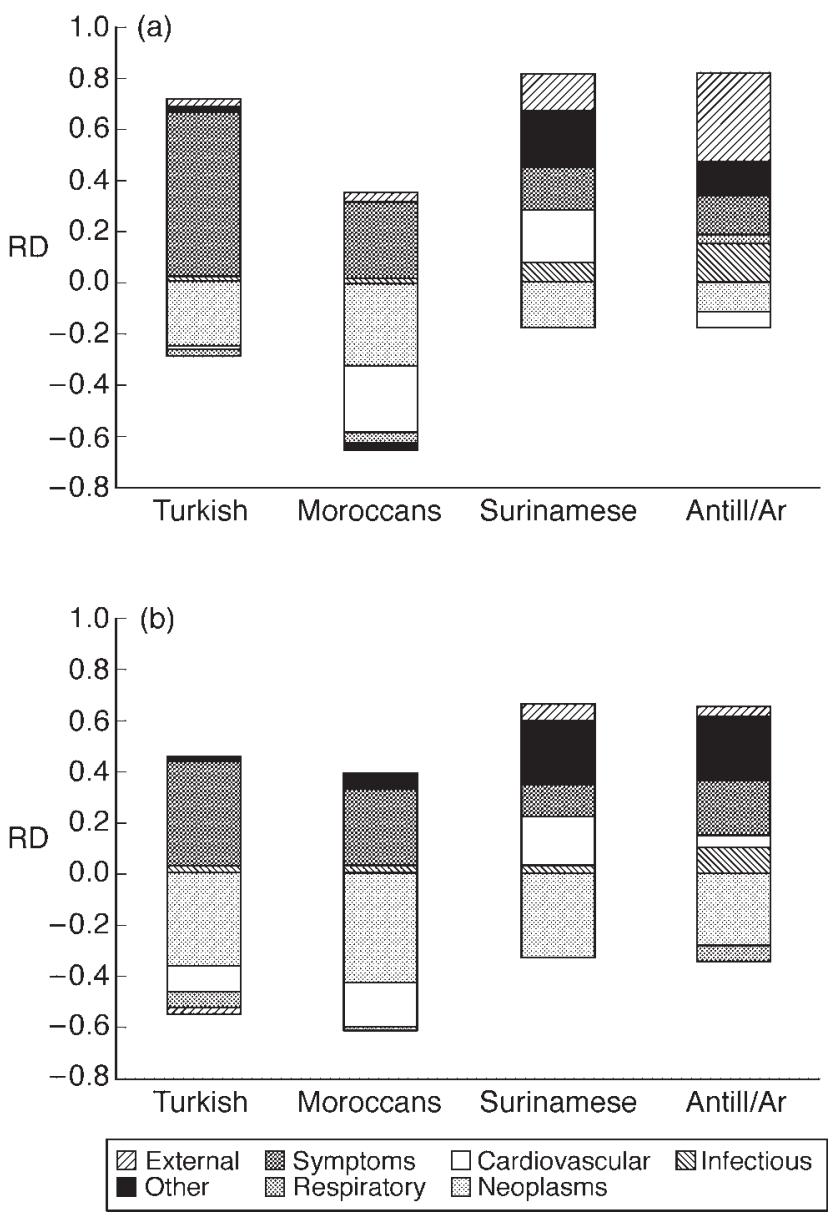

Figure 2 Differences between ethnic minorities and native Dutch in directly standardized death rates for specific causes of death: (a) Males, (b) Females

death, marital status and socio-economic status had a relatively large influence on mortality from infectious diseases and external causes (results not shown).

In all groups, but among Turkish and Moroccans in particular, excess mortality from symptoms, signs and ill-defined conditions made a large contribution to the differences in allcause mortality (Figure $2 \mathrm{a}$ and $2 \mathrm{~b}$ ). Low mortality from neoplasms compensated for the excess mortality from other causes of death among all groups. Among Surinamese and Antillean/Aruban males, external causes and infectious diseases made a contribution to the excess mortality, as did cardiovascular disease mortality among all Surinamese. Among Moroccan men, a lower cardiovascular mortality shifted the balance from higher towards lower all-cause mortality.

\section{Discussion}

Compared with native Dutch men, mortality was higher among Turkish $(\mathrm{RR}=1.21,95 \% \mathrm{CI}: 1.16,1.26)$, Surinamese $(\mathrm{RR}=$ 1.24, 95\% CI: 1.19, 1.29), and Antillean/Aruban ( $\mathrm{RR}=1.25$, 95\% CI: 1.15, 1.36) males, and lower among Moroccan males
$(\mathrm{RR}=0.85,95 \% \mathrm{CI}: 0.81,0.90)$. Among females, inequalities in mortality were small. In general, mortality differences were influenced by socio-economic and marital status. Most minority groups had a high mortality at young ages and low mortality at older ages, a high mortality from ill-defined conditions (which is related to mortality abroad) and external causes, and a low mortality from neoplasms. Cardiovascular disease mortality was low among Moroccan males ( $\mathrm{RR}=0.51,95 \% \mathrm{CI}: 0.44,0.59)$ and high among Surinamese males $(\mathrm{RR}=1.13,95 \% \mathrm{CI}: 1.05$, $1.21)$ and females ( $\mathrm{RR}=1.14,95 \% \mathrm{CI}: 1.06,1.23)$. Homicide mortality was elevated in all groups.

There are several factors that may have influenced the results of this study. Firstly, we were not able to address ethnic variations within migrant groups. Mortality differences for specific ethnic groups may have been larger and, especially for the ethnically diverse Surinamese and Antillean/Aruban population, this may have resulted in underestimated mortality differences. Secondly, since the cause of most deaths that took place abroad is unknown, the level of mortality for specific causes of death was underestimated. We re-analysed the data and redistributed deaths that took place abroad proportionally to the known causes of death. Upon this redistribution, levels of significance altered for some causes of death, but mortality patterns remained largely the same. ${ }^{12}$ Thirdly, there may have been a residual effect of socio-economic status, because we controlled for differences in socio-economic status by using an ecological measure and because indicators of socio-economic status do not necessarily have the same validity for all ethnic groups. ${ }^{5,10}$ Further adjustment for socio-economic status would most likely diminish differences in total mortality, but we think it is unlikely that this would eliminate the strong variations in age- and cause-specific mortality. Fourthly, since the age limits of the labour-related migration may have been an incentive to overestimate their age, the mortality level of Turkish and Moroccan men who were young in the 1960s and the 1970s may have been underestimated. Fifthly, unregistered remigration could have resulted in inaccurate denominator figures. ${ }^{13}$ Perople who re-migrate without de-registering were eventually 'administratively excluded' from the Dutch population registry. By taking into account numbers of 'administratively excluded' and estimations of mortality rates among the administratively excluded, we assessed whether unregistered remigration could have influenced our results, and observed that it is unlikely that it did so substantially (results not shown).

To identify factors that determined whether ethnic minority groups have higher or lower mortality than the native population, we compared levels of total and cause-specific mortality of comparable groups living in different countries. Three factors featured repeatedly. Firstly, in many countries, mortality that took place abroad was not or (very) incompletely included in the registry, while it was included in the Dutch registry. This may, for example, in large part explain why Turkish in Germany had a lower mortality level than Germans, while the mortality level of Turkish in The Netherlands was much less advantageous. ${ }^{14}$ Mortality abroad was very high among Turkish in The Netherlands. Upon exclusion of all these deaths, Turkish in The Netherlands would seem to have lower mortality than Dutch (results not shown). Secondly, a lower 
mortality from cancers is often found among non-Western ethnic minority populations, also among groups with high overall levels of mortality. ${ }^{15-21}$ It seems, however, that groups who had lower mortality than the native population, such as Moroccan males in The Netherlands and in France, Caribbean males in the UK, Hispanic males and females in the US, and Turkish males and females in Germany, all had low mortality from both cancer and cardiovascular diseases. ${ }^{1,14,15,22}$ Thirdly, in some groups, specific circumstances seemed able to shift the balance from a low to a high all-cause mortality. Antillean/Aruban men in The Netherlands, for example, had, like Caribbean men in the UK, low levels of mortality from both cardiovascular diseases and cancers. ${ }^{1,18}$ But contrary to Caribbean men in the UK, Antillean/Aruban men in The Netherlands had an excess mortality compared with the native population, which was largely due to high mortality from homicide and infectious diseases.

Two selection effects may have determined the observed mortality differences. Favourable health outcomes of migrants are often thought to be related to the selective migration of healthy individuals to the host country. Health selection effects do not affect the second generation and are reported to decrease over time. ${ }^{23}$ If this later finding is correct, this implies that only the mortality level of a relatively small group of people who entered The Netherlands more recently would still be affected by the healthy migrant effect. Furthermore, it is questionable how strong health selection effects will be, because most migrants migrate at an age at which symptoms of the major causes of death are rarely present. Therefore, we think it is unlikely that the healthy migrant effect had a large influence on the mortality level of the studied groups and on groups abroad with similar migration histories.

Another explanation of favourable health outcomes that is often mentioned is the selective (r)emigration of a relatively unhealthy subsample of migrants. ${ }^{24}$ The population that is left in the host country is then a relatively healthy one. Of those included in the population register between 1995 and 2000, mortality abroad in the period 1995-2000 is included in our database. Selective (r)emigration of an unhealthy sample of these people can therefore only influence our results as far it applies to registered (r)emigration, which is a relatively rare event in The Netherlands, and which therefore cannot have had a strong influence on our results. Of more importance may be the selective (r)emigration of people who left the Netherlands prior to 1995 . About $20 \%$ of the Surinamese and Moroccan population, about $30 \%$ of the Turkish population and about $40 \%$ of the Antillean/Aruban population who migrated between 1972 and 1995 left The Netherlands before 1995. ${ }^{25}$ The health or socio-economic status of these people is unknown and may have been better or worse than that of those who remained in The Netherlands. If the (r)emigrants were indeed a selective group, than the people who remained in The Netherlands are a selective group as well and this may therefore have influenced their levels of mortality.

To identify factors that determine ethnic differences in mortality we also examined factors that causally relate ethnicity with mortality. We demonstrated that socio-economic inequalities were a sizeable cause of inequalities in mortality by country of origin. In additional analyses (results not shown) we studied socio-economic differences in mortality within minority groups, using the same indicator of socio-economic status as in this study. Death rates were substantially influenced by socio-economic status in all groups. Socio-economic inequalities in mortality were, however, relatively small among Moroccans and large among Antilleans/Arubans. These results also suggest that ethnic inequalities in mortality are underpinned by socio-economic inequalities. Variations in the size of the socioeconomic mortality differences may have contributed to variations in the size of ethnic mortality differences.

We also showed that marital status can have a rather strong effect on ethnic differences in mortality. The mortality level of Surinamese and Antilleans/Arubans is increased due to the fact that they are often single, which includes being a lone parent, both statuses being related to an increased mortality. Whether this is due to differences in behavioural factors, or to the psychosocial consequences of being single, is unknown and needs further research.

Ethnicity is also related to mortality through lifestyle and risk factors. Turkish, Surinamese, and Antillean/Aruban men in The Netherlands currently smoke more than Dutch. ${ }^{26}$ Yet, we observed a low mortality from lung cancer among all minority groups. Since the lag time for developing lung cancer is long, this implies that older migrant males are less likely to have smoked heavily at a young age than older Dutch men, which corresponds with what is known about the smoking epidemic in less-developed countries. ${ }^{27}$ The high current prevalence of smokers reflects a tendency to adopt behaviour common in the host country. Not only lung cancer mortality, but also mortality from other cancers and cardiovascular diseases is related to smoking. Turkish and Moroccans have a Mediterranean diet and this probably had a positive influence on their mortality from cardiovascular disease. ${ }^{28}$ The high cardiovascular mortality among Surinamese is probably partially related to the high prevalence of diabetes mellitus among the subgroup of Surinamese who originate from the Indian sub-continent. ${ }^{26}$

The studied minority groups obtained an important health gain from their migration to The Netherlands. ${ }^{4}$ However, most groups had higher mortality than the native population. In part, this was related to their relatively low socio-economic factors and/or disadvantageous marital status. Mortality from cardiovascular diseases, homicide, and mortality abroad seemed of particular importance for shifting the balance from a high towards a low all-cause mortality.

To reduce ethnic inequalities in mortality, inequalities by socio-economic position and marital status should be reduced. To prevent ethnic inequalities in mortality becoming more disadvantageous in the future, the further adoption of unhealthy Western lifestyles should be discouraged.

\section{Acknowledgements}

Funding by the Dutch Organisation for Scientific Research (NWO), Culture and Health programme, file-number 261-98-612. We thank Statistics Netherlands for the use of their data. We thank Karien Stronks, Anna Peeters, Fanny Janssen, Daan Uitenbroek, Barend Middelkoop, and two anonymous referees for their comments on earlier drafts of this paper. 


\section{KEY MESSAGES}

- Compared with native Dutch males, mortality was high among Turkish, Surinamese, and Antillean males, and low among Moroccan males.

- Among females, ethnic inequalities in mortality were small.

- Ethnic inequalities in mortality were partly related to the relatively low socio-economic status of ethnic minorities and to the fact that, in some groups, being single was relatively common.

- Mortality from cardiovascular diseases, homicide, and mortality abroad were of particular importance for shifting the balance from high towards low all-cause mortality.

\section{References}

${ }^{1}$ Davey Smith G, Chaturvedi N, Harding S, Nazroo J, Williams R. Ethnic inequalities in health: a review of UK epidemiological evidence. Critical Public Health 2000; 10:375-408.

2 Davey Smith G, Neaton JD, Wentworth D, Stamler R, Stamler J. Mortality differences between black and white men in the USA: contribution of income and other risk factors among men screened for the MRFIT. MRFIT Research Group. Multiple Risk Factor Intervention Trial. Lancet 1998;35:934-39.

${ }^{3}$ Fang J, Madhavan S, Alderman MH. Nativity, race, and mortality: influence of region of birth on mortality of US-born residents of New York City. Hum Biol 1997;69:533-44.

${ }^{4}$ World Health Organization. World Health Statistics Annual. Geneva: World Health Organization; 1998.

${ }^{5}$ Davey Smith G. Learning to live with complexity: ethnicity, socioeconomic position, and health in Britain and the United States. Am J Public Health 2000;90:1694-98.

${ }^{6}$ Es D van. The Migrant as a Patient. (De migrant als patiënt). Utrecht: De Tijdstroom; 1995; [Published in Dutch]

${ }^{7}$ Uitenbroek DG, Verhoeff AP. Life expectancy and mortality differences between migrant groups living in Amsterdam, The Netherlands. Soc Sci Med 2002;54:1379-88.

${ }^{8}$ Hoogenboezem J, Israëls AZ. Mortality by cause of death in Turkish and Moroccan residents of the Netherlands 1979-1988. (Sterfte naar doodsoorzaak onder Turkse en Marokkaanse ingezetenen in Nederland 1979-1988). Maandbericht Gezondheid 1990;8:5-20; [Published in Dutch].

${ }^{9}$ Keij-Deerenberg IM Numbers of foreigners according to several definitions (Aantallen allochtonen volgens verschillende definities). Maandstatistiek bevolking 2000;5:14-17; [Published in Dutch].

${ }^{10}$ Bos V, Kunst AE, Mackenbach JP. The size of socio-economic inequalities in mortality measured at the neighbourhood level: comparison with estimations on the basis of information at the individual level. (De omvang van sociaal-economische sterfteverschillen gemeten op buurtniveau: vergelijking met schattingen op basis van informatie op individueel niveau). In: Stronks K (ed.). Socioeconomic Inequalities in Health: From Explanation to Reduction. (Sociaaleconomische gezondheidsverschillen: Van verklaren naar verkleinen). Den Haag: ZonMW, 2001, pp. 8-20 [Published in Dutch].

${ }^{11}$ Bos V, Kunst AE, Mackenbach JP. Socio-economic inequalities in mortality in the Netherlands: analyses on the basis of information at the neighbourhood level. (Sociaal-economische sterfteverschillen in Nederland: een analyse op basis van buurtgegevens). J Health Sci (Tijdschrift voor Gezondheidswetenschappen) 2002;80:158-65 [Published in Dutch].
12 Garssen J, Bos V, Kunst AE, Meulen A. vd. Mortality chances and causes of death in non-western foreigners. (Sterftekansen en doodsoorzaken van niet-westerse allochtonen). Bevolkingstrends 2003;3:12-27 [Published in Dutch].

${ }^{13}$ Weitoft GR, Gullberg A, Hjern A, Rosen M. Mortality statistics in immigrant research: method for adjusting underestimation of mortality. Int J Epidemiol 1999;28:756-63.

${ }^{14}$ Razum O, Zeeb H, Gerhardus A. Cardiovascular mortality of Turkish nationals residing in West Germany. Ann Epidemiol 1998;8:334-41.

15 Courbage Y, Khlat M. Mortality and causes of death of Moroccan in France, 1979-91. Population 1995;50:7-32.

${ }^{16}$ Glanz K, Croyle RT, Chollette VY, Pinn VW. Cancer-related health disparities in women. Am J Public Health 2003;93:292-98.

17 Bhopal RS, Rankin J. Cancer in minority ethnic populations: priorities from epidemiological data. Br J Cancer 1996;29(Suppl.):S22-32.

18 Grulich AE, Swerdlow AJ, Head J, Marmot MG. Cancer mortality in African and Caribbean migrants to England and Wales. Br J Cancer 1992;66:905-11.

19 Swerdlow A. Mortality and cancer incidence in Vietnamese refugees in England and Wales: a follow-up study. Int $J$ Epidemiol 1991;20:13-19.

${ }^{20}$ Fang J, Madhavan S, Alderman MH. Cancer mortality of Chinese in New York City 1988-1992. Int J Epidemiol 1996;25:907-12.

${ }^{21}$ Zeeb H, Razum O, Blettner M, Stegmaier C. Transition in cancer patterns among Turks residing in Germany. Eur J Cancer 2002;38:705-11.

22 Sorlie PD, Backlund E, Johnson NJ, Rogot E. Mortality by Hispanic status in the United States. JAMA 1993;270:2464-68.

${ }^{23}$ Williams R. Health and length of residence among south Asians in Glasgow: a study controlling for age. $J$ Public Health Med 1993; 15:52-60.

${ }^{24}$ Abraido-Lanza AF, Dohrenwend BP, Ng-Mak DS, Turner JB. The Latino mortality paradox: a test of the 'salmon bias' and healthy migrant hypotheses. Am J Public Health 1999;89:1543-48.

25 Statistics Netherlands. Foreigners in the Netherlands (Allochtonen in Nederland) Voorburg: Statistics Netherlands, 2003, [Published in Dutch].

${ }^{26}$ Leest LATM, Koek HL, Bots ML, Verschuren WMM. Cardiovascular Diseases in the Netherlands 2002, Figures about Disease and Mortality. (Harten vaatziekten in Nederland 2002, cijfers over ziekte en sterfte). Den Haag: Nederlandse Hartstichting, 2002, [Published in Dutch].

27 Olsen JH. Epidemiology of lung cancer. Eur Respir Monogr Lung Cancer 1995;1:1-17.

${ }^{28}$ Trichopoulou A. Mediterranean diet: the past and the present. Nutr Metab Cardiovasc Dis 2001;11:1-4. 